\title{
Hypocalcaemic myopathy with paranoid psychosis
}

\author{
J. A. SNOWDON, A. C. MACFIE, AND J. B. PEARCE \\ From the Maudsley Hospital, London
}

SYNOPSIS A description is given of a patient with idiopathic hypoparathyroidism and a paranoid psychosis. Changes in muscle, electromyograms, and blood enzyme levels were related to hypocalcaemia. Reference is made to the elevations of these enzyme levels found in other cases of psychosis.

Psychiatric and neurological manifestations of hypoparathyroidism are relatively well documented (Simpson, 1952), but reports of myopathy in association with hypoparathyroid conditions are rare. The patient described below has a paranoid psychosis as well as idiopathic hypoparathyroidism; details of his presentation and treatment will be described elsewhere (Macfie et al., in preparation). We report here evidence that he had a myopathy in association with his hypoparathyroidism. Myopathy is said to be quite common in psychosis.

\section{CASE REPORT}

The patient, then aged 64 years, and working as a messenger, complained in 1969 of a sensation of insects running up his legs. The idea diminished when he was admitted to hospital (and before he started any medication). Since that time, at irregular intervals, he has described similar sensations; during these episodes auditory hallucinations and paranoid ideation have usually been obvious. At times it seemed that these phenomena became evident when the level of serum calcium rose towards normal; recently his mental state has changed little in spite of considerable fluctuation of his serum calcium.

He has a past history of osteoarthritis of his right elbow, migraine, and an operation for varicose veins. Physical examination in hospital in 1969 revealed a blood pressure of $190 / 100 \mathrm{mmHg}$, a mitral systolic murmur, bilateral external rectus palsies (present since birth), bilateral cataracts, and mild but continuous proteinuria. There was no weakness or demonstrable abnormal sensation of the limbs or body. His erythrocyte sedimentation rate (ESR) varied from 44 to $76 \mathrm{~mm} /$ hour, his plasma urea

(Accepted 7 July 1975.)

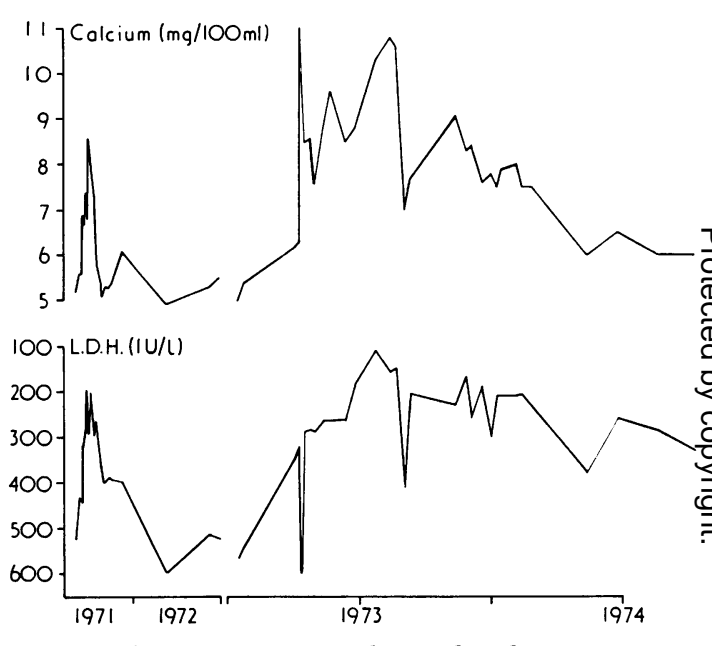

FIG. 1 Showing inverse relationship between serum levels of calcium and lactic dehydrogenase.

was $9.5 \mathrm{mmol} / 1(57 \mathrm{mg} / \mathrm{dl})$, red cells were seen in his urine, but an intravenous pyelogram showed normal kidneys. An electrocardiogram showed left axis deviation but no evidence of hypocalcaemia.

In October 1971 he was admitted to a general hospital for cataract extractions, and he was found to have hypocalcaemia. Since then, a diagnosis of idiopathic hypoparathyroidism has been made, on evidence to be presented in another paper (Macfie et al., in preparation). Over the next few weeks, while an aetiological diagnosis and also correction of the hypocalcaemia were being attempted, frequent estimations of serum calcium were made and, because these were performed on an autoanalyser, it has been possible to compare the changes in serum calcium with those of serum lactic dehydrogenase (LDH) (Fig. 1) as well as of serum aspartate aminotransferase (SGOT) and other serum enzymes. 
Serum bilirubin, alkaline phosphatase, and total protein remained normal and almost unchanged throughout this period, and variations in uric acid, cholesterol, and blood urea nitrogen bore no obvious relation to changes in serum calcium and LDH. The SGOT rose abruptly one week after the patient commenced oral calcium and calciferol, and while it was raised the changes in serum LDH bore some relation to those of SGOT; while the SGOT was within normal limits there was no obvious relation between the two.

In December 1971 his cataracts were extracted and he had a prostatectomy. He was in hospital from May 1972 to March 1974, apart from a few weeks each in late 1972 and late 1973, because he was again psychotic. In November 1972 he had a left central retinal artery occlusion. He was discharged home in March 1974, still describing auditory hallucinations and paranoid delusions, and his mental state (which conformed with that of late paraphrenia) remained essentially unchanged during the next year. During all this time, there have been no muscular weakness (apart from the lateral rectus palsies), signs of myotonia, or demonstrable abnormality of sensation. Fasciculation has been noted around both shoulders. While the serum calcium level was low, tetanic spasm could be induced by Trousseau's method.

Because the LDH had previously been elevated, serum enzyme levels have been measured and liver function tests repeated on a number of occasions during the last three years. Electromyograms (Dr

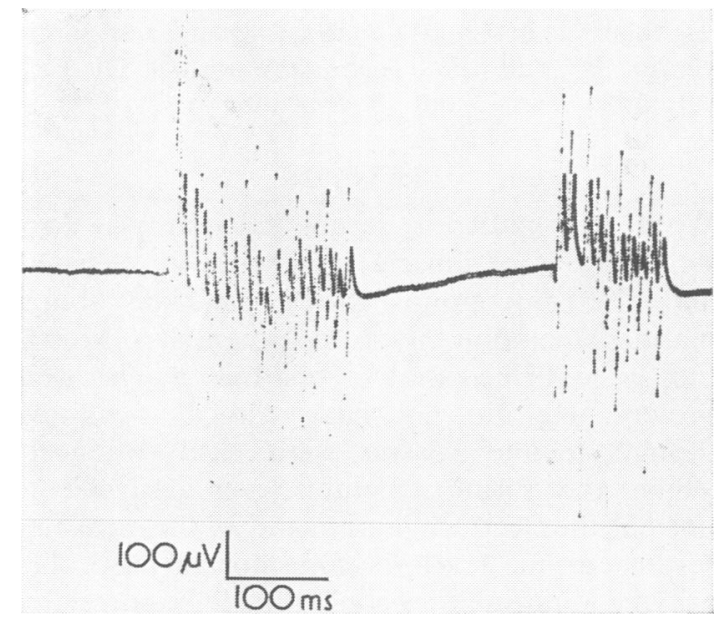

FIG. 2 EMG showing bursts of spontaneous repetitive motor unit potentials (forearm extensor muscle group).

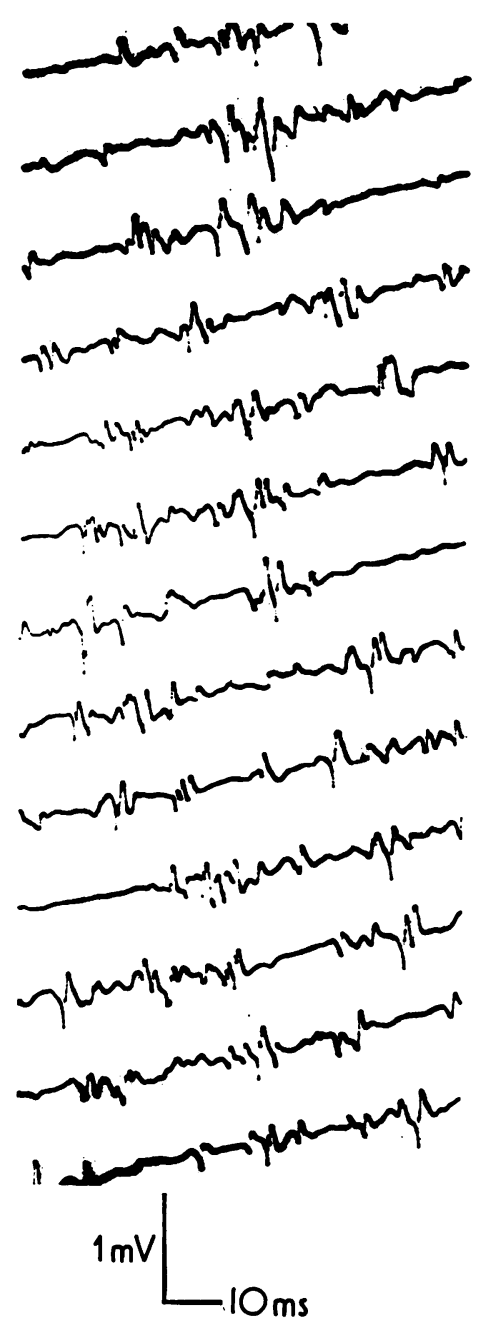

FIG. 3 EMG showing small amplitude polyphasic motor unit action potentials on moderate effort (forearm extensor muscle group).

Ruth Harris) during two different episodes when the serum calcium was about $1.3 \mathrm{mmol} / 1(5.5 \mathrm{mg} / \mathrm{dl})$ showed bursts of spontaneous motor unit potentials in groups of variable number (Fig. 2), and these are typical of hypocalcaemia. But, in addition, these electromyograms also showed long trains of spontaneous potentials, sometimes lasting over a minute (Fig. 3). A biopsy of tibialis anterior muscle (Dr L. W. Duchen) showed marked myopathic changes (Fig. 4); many fibres contained central nuclei, and there was disorganization of myofibrils, 'ring-forms' being very numerous. Occasional 'cytoplasmic bodies' were seen. Some fibres were necrotic, while 


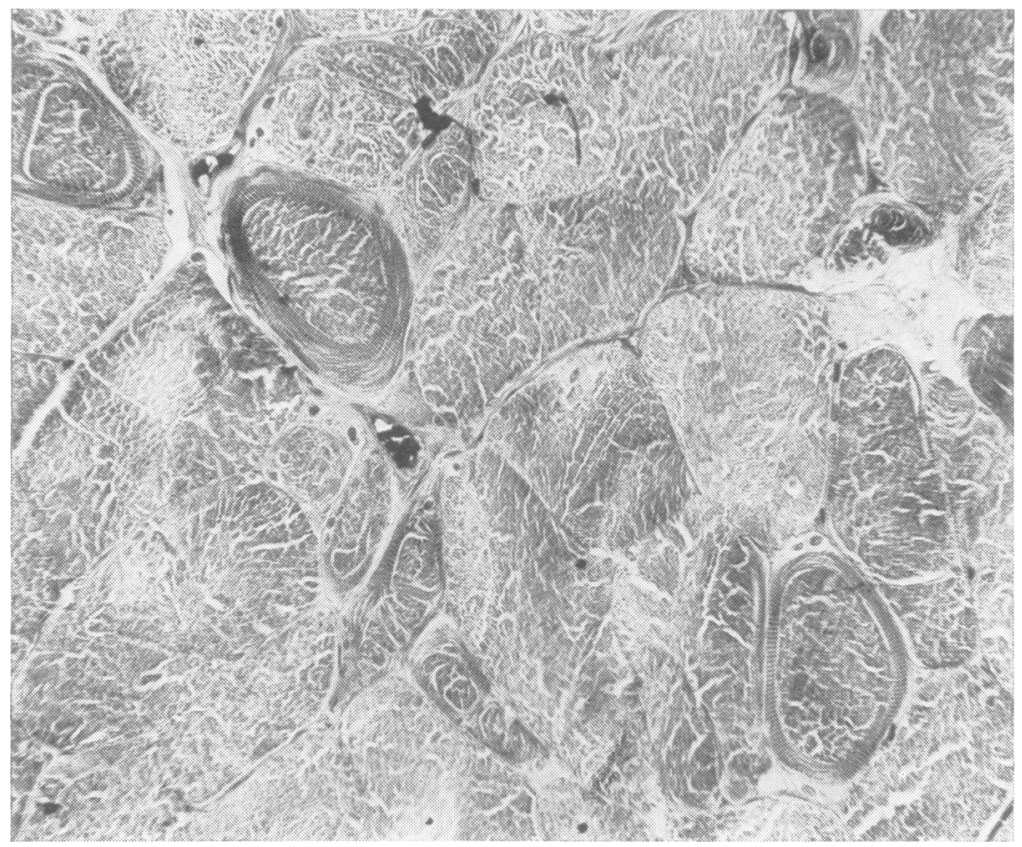

FIG. 4 Transverse section of muscle biopsy of tibialis anterior. In this field, many of the muscle fibres show disorganization of myofibrils which have a transverse or oblique orientation to the long axis of the muscle fibre. Some of the larger fibres show well defined annulets ('ringbinden'). Heidenhain's trichrome, $\times 200$.

in others there was an infiltration of reactive cells. On 11 April 1973 the patient was given a calcium infusion and, two days later, when his serum calcium level was $2.37 \mathrm{mmol} / 1(9.5 \mathrm{mg} / \mathrm{dl})$, the electromyogram was reported as normal. On 4 May 1973, when the serum calcium level was $2.1 \mathrm{mmol} / 1(8.4 \mathrm{mg} / \mathrm{dl})$, sparse fibrillation was noted, but there were no myotonic trains and no bursts of motor unit activity.

He has been treated with phenothiazines, but changes in serum enzyme levels were unrelated to use of these drugs. After the calcium infusion, serum levels of $\mathrm{LDH}$, hydroxybutyric dehydrogenase (HBD), and unconjugated bilirubin rose abruptly (total bilirubin $35.9 \mu \mathrm{mol} / 1(2.1 \mathrm{mg} / \mathrm{dl})$ ), while the SGOT and creatine phosphokinase (CPK) were virtually unchanged. The levels rapidly fell again. The CPK remained normal for many months after the infusion, even though intramuscular injections of vitamin D and oral phenothiazines were administered. However, the CPK level rose to well over 100 IU/1 (normal range 0 to 50 ) when the serum calcium fell below $1.75 \mathrm{mmol} / 1(7.0 \mathrm{mg} / \mathrm{dl})$.

Results of other investigations which are relevant to a discussion of the muscle abnormality are: blood urea $7.0-14.0 \mathrm{mmol} / 1$ (42-85 mg/dl), creatinine $150 \mu \mathrm{mol} / \mathrm{l}(1.6 \mathrm{mg} / \mathrm{dl})$ with clearance $71 \mathrm{ml} / \mathrm{minute}$; proteinuria $525 \mathrm{mg} / 24$ hours, but urinalysis showed no other significant abnormality. Protein-bound iodine level was $615-851 \mathrm{nmol} / \mathrm{l}(7.8$ to $10.8 \mu \mathrm{g} / \mathrm{dl})$ (unrelated to medication), but other thyroid function tests were normal. Tests for antibodies were negative (except, in 1971, one recording of a high titre of 'diffuse' and 'membraneous' antibodies); no lupus erythematosus cells were found. Protein electrophoresis has shown raised alpha ${ }_{2}$ and slight rise in gamma globulin in serum; IgM was $2.5 \mathrm{~g} / \mathrm{l}$ (normal less than 1.1) in serum. Glucose tolerance test, serum vitamin $\mathbf{B}_{12}$ and folate levels were normal. His ESR varied between 42 and $73 \mathrm{~mm} /$ hour.

\section{DISCUSSION}

While this patient's serum calcium was low, serum levels of muscle enzymes were elevated, and electromyograms showed marked abnormalities (including myotonic potentials). Muscle biopsy confirmed that myopathic changes were present. He did not have clinical weakness, though tetanic spasms were easily induced. When the serum calcium level returned to normal, the electromyogram and all the measured serum enzyme levels became normal also. The enzyme abnormalities could clearly be correlated with the abnormal calcium level. Suspicions of an alternative aetiology for the myopathy were raised by abnormal results of other investiga- 
tions, in particular the raised ESR, blood urea nitrogen, and protein-bound iodine; however, the fact that these results remained abnormal, but the signs of myopathy disappeared, when the serum calcium was restored to a normal level, strongly suggests that the myopathy was due to or related to abnormal calcium metabolism. Clearly, this patient has renal disease, and the protein-bound iodine is thought to be elevated because of diminished renal clearance. We do not know why the ESR is raised. A renal biopsy has not been possible; there was no evidence of collagen disease or amyloid in the muscle biopsy specimen.

Myopathy has rarely been reported in association with hypoparathyroid conditions. Wolf and Lusk (1972) give a full account of such a case after subtotal thyroidectomy, and review the literature; in other reports, the association is not so clearly demonstrated. Cape (1969) described myopathy in a case of pseudohypoparathyroidism; histochemical examination showed a lack of phosphorylase activity in the muscle, and Cape suggested that there had been insufficient calcium to activate phosphoryl kinase. His patient had muscular weakness, and serum levels of CPK, LDH, and aldolase were markedly elevated; the serum calcium level was between 1.25 and $1.65 \mathrm{mmol} / \mathrm{l}$ (5.0-6.6 $\mathrm{mg} / \mathrm{dl}$ ).

An inverse relationship between serum levels of calcium and LDH has been reported previously (Stoner et al., 1971); LDH returns to normal when hypocalcaemia is corrected (Zondag and Klein, 1968; Wolf and Lusk, 1972). This pattern is apparent in our own case $(r=-0.76)$, in which a similar relationship with $\mathrm{HBD}$ was present but less obvious $(r=-0.60)$. There was also a clear inverse correlation between serum levels of calcium and CPK $(r=-0.76)$. Elevated $\mathrm{CPK}, \mathrm{LDH}$, and aldolase levels were found in two patients with hypocalcaemia described by Hower et al. (1972). It seems that increased membrane permeability (leading to enzyme release) results from hypocalcaemia. In our case it is of interest that the SGOT remained normal except for a transient and unexplained elevation in November 1971.

Elevation of serum CPK has been found in about $50 \%$ of acutely psychotic patients (Meltzer and Moline, 1970; Gosling et al., 1972; Schweid et al., 1972), though Harding (1974) could not confirm these findings; reports differ about whether LDH and/or SGOT are often concomitantly raised. Generally the CPK levels return to normal within a few days to weeks; increased CPK activity has been found in $7.8 \%$ of nonpsychotic patients (Meltzer et al., 1971). These findings are of some interest in our own case; on three occasions it seemed that raising his serum calcium level resulted in reemergence of his psychosis, though in the last two years the converse has not applied-he remained deluded except for a few months in 1975. His CPK level was not measured while his mental state was normal; in January 1973, soon after he was admitted, it was found to be elevated, but he was still psychotic even when the serum levels returned to normal. Muscle biopsies have shown myopathic changes in over $40 \%$ of acutely psychotic patients (Meltzer and Engel, 1970; Engel and Meltzer, 1970), but serum calcium levels were not reported in these studies. We suggest that investigation should be made into the relationship of calcium metabolism and ion exchange to abnormal muscle enzyme levels in cases of psychosis.

Many thanks are due to Dr Raymond Levy for his encouragement, and for giving permission to publish this account of a case under his care. We also sincerely thank Dr L. W. Duchen for his report of the biopsy findings and for providing Fig. 4, Dr Ruth Harris for her electromyogram studies (Figs 2 and 3), and Dr H. M. B. Buckell, Dr F. Post, and Dr J. Crammer for their valuable help and advice.

\section{REFERENCES}

Cape, C. A. (1969). Phosphorylase $a$ deficiency in pseudohypoparathyroidism. Neurology (Minneap.), 19, 167-172.

Engel, W. K., and Meltzer, H. (1970). Histochemical abnormalities of skeletal muscle in patients with acute psychoses. Part 1. Science, 168, 273-276.

Gosling, R., Kerry, R. J., Orme, J. E., and Owen, G. (1972). Creatine phosphokinase activity in newly admitted psychiatric patients. British Journal of Psychiatry, 121, 351-355.

Harding, T. (1974). Serum creatine kinase in acute psychosis. British Journal of Psychiatry, 125, 280-285.

Hower, J., Struck, H., Tackmann, W., and Stolecke, H. (1972). C.P.K. activity in hypoparathyroidism. New England Journal of Medicine, 287, 1098.

Meltzer, H. Y., and Engel, W. K. (1970). Histochemical abnormalities of skeletal muscle in acutely psychotic patients. Part 2. Archives of General Psychiatry, 23, 492502. 
Meltzer, H. Y., and Moline, R. (1970). Muscle abnormalities in acute psychoses. Archives of General Psychiatry, 23, 481-491.

Meltzer, H. Y., Nankin, R., and Raftery, J. (1971). Serum creatine phosphokinase activity in newly admitted psychiatric patients. Part 2. Archives of General Psychiatry, 24, 568-572.

Schweid, D. E., Steinberg, J. S., and Sudak, H. S. (1972). Creatine phosphokinase and psychosis. Archives of General Psychiatry, 26, 263-265.

Simpson, J. A. (1952). The neurological manifestations of idiopathic hypoparathyroidism. Brain, 75, 76-90.
Stoner, R. E., Williams, J. B., Connor, T. B., and Brager, S. H. (1971). Inverse relationship between serum calcium concentration and serum lactic dehydrogenase activity. Metabolism, 20, 464-473.

Wolf, S. M., and Lusk, W. (1972). Hypocalcemic myopathy. Bulletin of the Los Angeles Neurological Societies, 37, 167177.

Zondag, H. A., and Klein, F. (1968). Clinical applications of lactate dehydrogenase isozymes: alterations in malignancy. Annals of the New York Academy of Sciences, 151, 578-586. 